Research Article

\title{
Online Event Management on Twitter in the Covid-19 Pandemic Process: The Example of the Ministry of Culture and Tourism
}

\author{
Simge Ünlü (Assoc. Prof. Dr.) \\ Sakarya University Faculty of Communication \\ simgeunlu@sakarya.edu.tr \\ Lütfiye Yaşar (MA Student) \\ iD Sakarya University Institute of Social Sciences \\ lutfiye.yasar1@ogr.sakarya.edu.tr
}

Date Received: 20.03.2021

Date Accepted: 10.05.2021

Date Published: 30.07.2021

https://doi.org/10.17680/erciyesiletisim.900433

\begin{abstract}
In this study, Twitter in local and global online activity management organized to create a sense of community by the Ministry of Culture and Tourism during the COVID-19 pandemic process was analyzed. The Ministry's Twitter posts were analyzed using the thematic analysis method between March 11 and June 30, 2020. The Ministry has implemented many local and global activities planned to be conducted by social distance and hygiene rules through virtual environments during the COVID-19 pandemic process. These online activities are planned and managed online with both national and international cooperation to increase positive emotions and thoughts in society and reducing the spread of negative emotions caused by the COVID-19 epidemic. In this context, it is seen that the Ministry has undertaken a task of organizing online events that entertain the Public since the COVID-19 epidemic started and making informative sharing by using the official Twitter account of the Ministry. Because of the research, it was determined that the correct planning and implementation of online activities within the framework of the corporate vision and mission aroused interest in the target audience and increased the number of followers of the Ministry's Twitter account.
\end{abstract}

Keywords: Public Relations, Online Event Management, Social Media, Ministry of Culture and Tourism, Covid-19 Pandemic. 


\title{
Covid-19 Pandemisi Sürecinde Twitterda Online Etkinlik Yönetimi: Kültür ve Turizm Bakanlığı Örneği
}

\author{
Simge Ünlü (Doç. Dr.)
}

Sakarya Üniversitesi Illetişim Fakültesi

simgeunlu@sakarya.edu.tr

Lütfiye Yaşar (Yüksek Lisans Öğrencisi)

iD Sakarya Üniversitesi Sosyal Bilimler Enstitüsü

luttiye.yasar1@ogr.sakarya.edu.tr

Başvuru Tarihi: 20.03.2021

Yayına Kabul Tarihi: 10.05.2021

Yayınlanma Tarihi: 30.07.2021

https://doi.org/10.17680/erciyesiletisim.900433

\section{Öz}

$\mathrm{Bu}$ araştırmada Covid-19 pandemisi sürecinde Kültür ve Turizm Bakanlı̆̆g'nın topluluk duygusu oluşturarak birliktelik sağlamak için düzenlenen yerel ve küresel ölçekteki online etkinlik yönetiminde Twitter kullanımı analiz edilmiştir. Bu amaçla 11 Mart-30 Haziran 2020 tarihleri arasında bakanlığın, Twitter paylaşımları tematik analiz yöntemiyle incelenmiştir. Bakanlığın Covid-19 pandemisi sürecinde sosyal mesafe ve hijyen kuralları gereğince yapılması planlanan yerel ve küresel ölçekteki birçok etkinliği sanal ortamlar aracılığıyla hayata geçirdiği belirlenmiștir. Topluluğun eğlendirilmesini amaçlayan bu online etkinlikler, Covid-19 salgınının oluşturduğu negatif duygu yayılımının azalmasını sağlamasıyla birlikte toplumda pozitif duygu ve düşünceleri artırmak amacıyla gerek ulusal gerekse uluslararası iş birliğiyle online olarak planlanıp yönetildiği bulgusuna ulaşılmıştır. Bu bağlamda Kültür ve Turizm Bakanlığı'nın resmi Twitter hesabından yararlanarak Covid-19 salgının başladığı süreçten itibaren kamuoyunu eğlendiren online etkinlikler organize eden ve bilgilendirici paylaşımlar yapan bir görev üstlendiği görülmektedir. Araştırma sonucunda online etkinliklerin kurumsal vizyon ve misyon çerçevesinde doğru planlanıp uygulamaya konulması hedef kitlede ilgi uyandırarak bakanlığın Twitter hesabının takipçi sayısında artış sağladığı tespit edilmiştir.

Anahtar Kelimeler: Halkla İlişkiler, Online Etkinlik Yönetimi, Sosyal Medya, Kültür ve Turizm Bakanlığı, Covid-19 Pandemi. 


\section{Introduction}

The world of today, where access to information is not complex, is defined as a global village by Duğan and Aydın (2018). According to Marshall McLuhan, the most prominent feature of our world is that information goes into a distribution process as fast as possible. According to Dadashzadeh (2010), the Internet essential for the evolution of communication to a different dimension. Bertot et al. (2010) are defined that the share of communication tools in accessing data cheaply and efficiently is an undeniable fact. Therefore, cheap and easily accessible data has contributed significantly to the diversification of communication tools.

Internet, which provides a considerable contribution to the beginning of a new period, led to the formation of different communication tools that can be considered revolutionary. With the introduction of new communication tools into our lives, institutions can establish a bidirectional interaction with their target audience through these tools to maintain their eigenvalues and create a pleasant perception in the memory of the target audience. According to Yi et al. (2013), in this digital world, which continues to evolve continuously, new media environments can increase the organization's existing communication, encourage public cooperation and data flow, and adapt to suddenly developing situations. Criado et al. (2013) argue that public institutions and bureaucracy exist in social media and increase the accessibility of public administrations in different social networks such as blogs and Twitter. Therefore, organizations can actively use Twitter to maintain and strengthen their relationship with the target audience they are influential.

Depending on the developments in technology, being in social media affects the visibility of individuals and institutions. Public institutions are also obliged to augment the image and fame of the organization in the minds in parallel with the active presence of the intended population in the virtual environment and provide data transfer to the Public (Ünlü, 2018a, s. 890-891). Therefore, institutions or organizations have to increase their effectiveness on social media. According to Sayımer (2008), social media can get data concerning the target audience and see what they think about any issue related to the institution and play the role that other media tools play interactively.

The Ministry of Culture and Tourism benefits from these social media communication activities, just as other institutions continue their social media communication activities. Depending on the technological advances, the Internet has access to every space and can be used widely, and accordingly, the Ministry of Culture and Tourism has turned its direction to this space. Twitter has a mutual interaction and a guiding effect in addition to its informative purpose. In other words, social media, which enables institutions to become a public symbol in the minds of those who are active, and also includes Twitter; which plays a considerable role in the communication services as it provides a basis for bidirectional interaction with the public and target audiences (Yıldırım, 2014, p. 236; Khasawneh \& Abu-Shanab, 2013, p. 10). Considering that today's social media can be used intensely by everyone, it is essential how and to what extent the Ministry of Culture and Tourism benefits from social media.

Public institutions, whose primary duty is to serve citizens, can undertake the obligation to use social media in order to provide more active, pathetic, that is, effective and efficient service (Ylldırım, 2014, p. 236). Due to the increasing trend of public institutions' target audience towards social media uses Facebook, Instagram, and Youtube accounts and 
Twitter accounts to increase the interaction with its target audience. Accordingly, the Ministry of culture and tourism, a public institution, can also use these accounts.

The Ministry of Culture and Tourism, like other ministries, is an undeniable fact of its importance for society. Social media usage has increased with the advances in technology and the acceleration of the Internet. Considering the impact of social media on institutions, how and for what goal the Ministry of culture and tourism used Twitter in the Covid-19 pandemic process was examined. As a consequence, the research is essential in terms of being a source for future studies.

The Ministry of Culture and Tourism, which has a considerable role in promoting works inherited from the past, aims to recognize the values at the essence of this heritage and increase awareness. Therefore, it operates on Twitter, an effective social media tool, and the institutions and organizations it communicates. Tourism is one of the areas most affected by curfews with the effect of the Covid-19 Pandemic. The goal of the research is to analyze the use of Twitter, one of the social media applications of the Ministry of Culture and Tourism, defined as the microblogging site, during the period when the Covid-19 pandemic began to affect our country intensively. This study was included in the research group that was not subject to ethics committee approval. Since there are not enough studies in the literature on social media activity management of public institutions, it is essential to analyze the use of Twitter of the Ministry of Culture and Tourism, which organizes online events during the pandemic process and evaluates the results. Additionally, this research is substantial in terms of providing references for future studies.

\section{Online Event Management in the Covid-19 Pandemic Process}

It is seen that the event industry and organized activities developed with the pandemic are a fundamental element of media tools. The activities have educational benefits in addition to their economic, cultural, and social benefits. Activities that assume a social role are a tool of institutional-based public relations (Ünlü, 2018a). Thus, activities are an effective method for reflecting the corporate perspective, communicating messages, promoting products/services, expressing responsibilities, and finally creating a positive image.

The online event management, which has increased with the pandemic, includes the entire process of planning activities such as celebrations, meetings, or promotions to strengthen corporate purposes such as image and reputation in addition to social integration or the perception of social responsibility adopted by the institution, managing the process in all its aspects, and further evaluations (Peltekoğlu, 2012; Işık \& Ayhan, 2007; Işık, 2013). Therefore, online event management describes an effort with a planned and devoted work with specific methods and stages such as lobbying and advertising, and promotion.

According to Goldblatt (1997), an activity is to do something different from daily life, and an activity planned online takes place in an obvious term of time, with many different purposes. In addition, each activity planned to be realized has a specific follower, program, and management (Getz, 2000). All of these factors make up the activity, and whether these activities take place in private life or social life, they create a sense of community together. Concert moments, which are one of the moments in which the feeling of unity is experienced in the society, started to be performed in the digital environment with the pandemic. The organizers of these virtual concerts were sometimes institutions and 
sometimes individuals. An 8-hour online concert was organized with the cooperation of Global Citizen and the World Health Organization. Nearly 1 million viewers watched the concert broadcast of pianist Gülsin Onay through social media accounts. While Cem Adrian gave a free concert on youtube, Singer Yalın gave his first live concert on Instagram. Santuri Sedat Anar gave a concert at the events on Üsküdar Municipality's Instagram and YouTube channel. In addition to all these activities, the online concert organized for April 23 National Sovereignty and Children's Day was broadcast on the YouTube channel of the Directorate of Communications (Anadolu Ajansl, 2021). BTS, which organized a concert with tickets online, became the most-watched concert with 756 thousand 600 tickets sold and with participants from 107 countries. In Turkey, the first ticketed concert online experiment was carried out by Mor ve Ötesi (Hürriyet, 2021). The first online live stadium concert in Turkey was watched by 5.7 million people on YouTube (Sabah, 2021).

The reasons for using virtual environments in online activities:

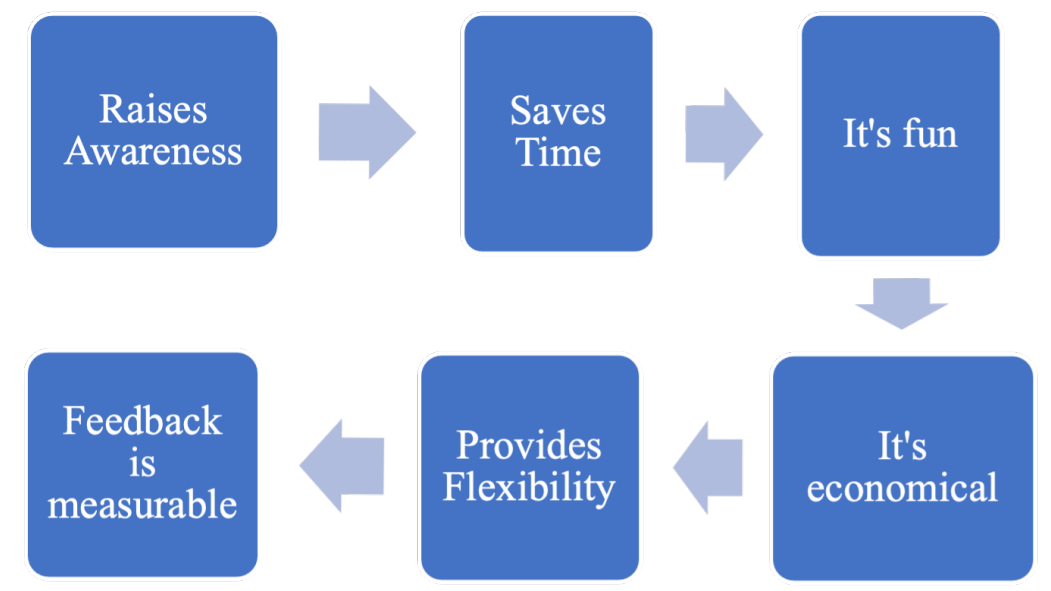

Source: Akay, 2014, p. 65

Even though today's events are performed to continue traditional actions, the size of the institutions or organizations that organize the event ensures that the event occurs on a global scale (Ünlü, 2018b, p. 17). The frequency and impact area of the activity is limited as major and minor events (Jago \& Shaw, 2000). While significant events are effective at regional and national scales, minor events are events such as cities and festivals (Syme, 1989). Concordantly, it is essential to provide that the activities are implemented in various dimensions, different scopes, and qualities. The message intended to be given as a public relations activity is conveyed with the right tool during this activation process. In the online event management process, it is also essential to plan and implement the process correctly to achieve the intended goals with the activity realized within the corporate vision and mission framework. An online event has six different effects: capital, economic, ecological, media, political, and finally, stakeholder effect. In addition to all these effects, considering the corporate reputation and customer loyalty, online event planning and management have various benefits in market competition. This advantage can be listed as energy efficiency, waste reduction, water consumption, ecological supply, communication, awareness, and sustainable development (Ünlü, 2018b, p. 40).

\section{Related Studies}

Because of the augment in the use of new media, individuals and institutions turned to social media to improve two-way communication. Additionally, studies on how institutions and organizations use social media tools in the online event management process. In this context, some of the previous studies are as follows; Becker et al. (2009); 
Paris et al. (2010); Gu et al., (2011); Bukhari et al., (2012); Pasanen and Tema (2016); Marine-Roig et al., (2017); Cottrill et al. (2017); Pino et al., (2019).

When the relevant studies are evaluated, there are works on event management in social media. Studies focus on marketing and media usage strategy in the event management process. This research aims to contribute to the local literature by focusing on public institutions' online event management strategy during the Covid-19 pandemic process.

\section{Thematic Analysis of Twitter Usage as an Online Event Management Platform in the Covid-19 Pandemic}

The Ministry of Culture and Tourism aims to recognize the core values of this heritage and increase awareness. Therefore, it operates online on Twitter, an effective social media tool and the institutions and organizations it is in contact with. Tourism is one of the most affected areas by curfew restrictions due to the pandemic effect. This study aims to examine the use of Twitter of the Ministry of Culture and Tourism, with the thematic analysis method, in the period when the Covid-19 pandemic began to affect our country intensively. The research has been analyzed with maxqda version 2020.03 .

Thematic content analysis is a form of reporting that determines the theme of the text examined and the text analysis. According to Castleberry and Nolen (2018), this method is complementary as it reveals the relationship between semantic links of a concept in the text with other concepts. The thematic analysis allows comparing these two data if the studied data are presented again (Alhojallan, 2012, p. 40). According to Vaismoradi et al. (2016, p. 100), the benefits of thematic analysis include providing systematic coding, definition, and semantic analysis. As a result, the thematic analysis method examines the researchers' opinions and determines the intersection areas of the studies, and determines the differences of the studies conducted. The questions of the research are listed as follows:

What are the contents of the Ministry's online activity shares on Twitter during the Covid-19 outbreak?

During the Covid-19 outbreak, did the Ministry of Culture and Tourism increase the number of followers on Twitter due to organizing an online event?

Did the Ministry use Twitter to entertain the Public during the Covid-19 outbreak?

The tweets shared by the Ministry of Culture and Tourism on Twitter, the official social media account of the Ministry between March 11 - June 30, 2020, were interpreted using the 2020.03 version of the Maxqda program.

\section{Findings}

In this part, the posts shared on the official Twitter sum of the Ministry of Culture and Tourism between March 11, 2020, and June 30, 2020, were analyzed using the thematic analysis method. The Ministry, whose Twitter account was opened in January 2011, has $225 \mathrm{~B}$ followers in March, and the number of people or institutions followed is 47 (TCKulturTurizm,2020). The number of followers in June is $247 \mathrm{~B}$, and the number of people or institutions followed is 49 (TCKulturTurizm,2020). In this case, the augment in the number of followers is $8.91 \%$, and the increasing graph is given below. 


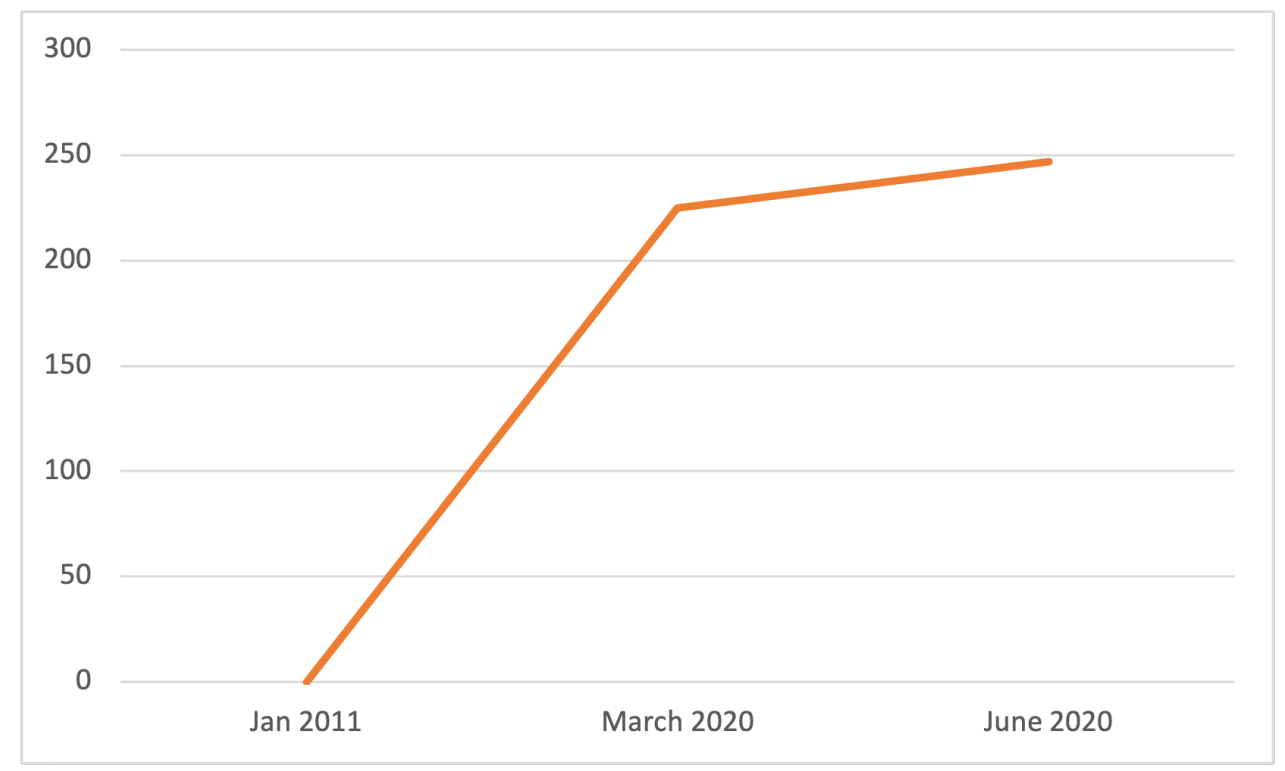

Chart 1. Follower growth chart of the Ministry

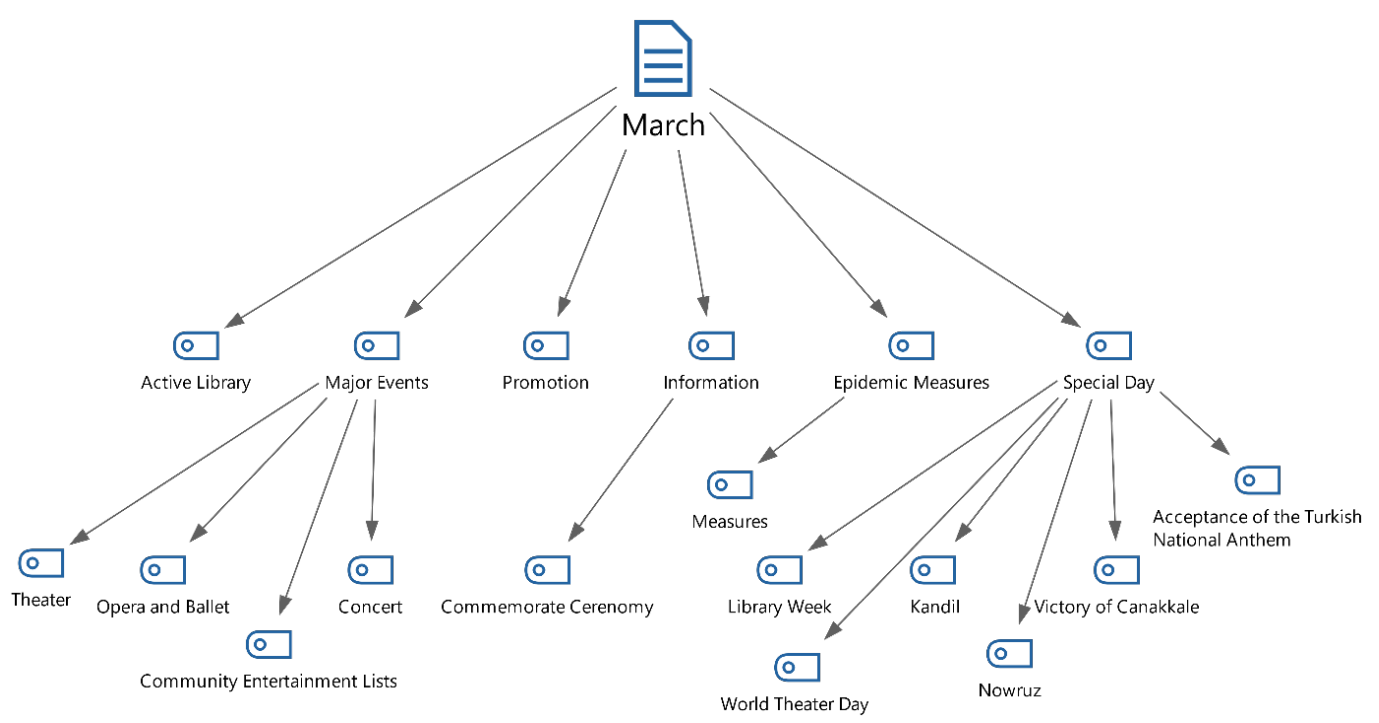

Figure 1. March tweet themes

The contents of the Ministry's Covid-19 pandemic's Twitter posts in March are as follows: In addition to the posts on the contents of the Active Library application, promotional announcements and informative posts about commemorating the artists who lost their lives were also shared. The Library Week, World Theater Day, Kandil, Nevruz Festival, Çanakkale Victory, and the Acceptance of the National Anthem are among the particular day sharing, which includes the measures taken regarding the epidemic measures and special day events. There are lists of theater, opera, ballet performances, concerts, and, finally, online events to entertain the community in the significant online event sharing category. 


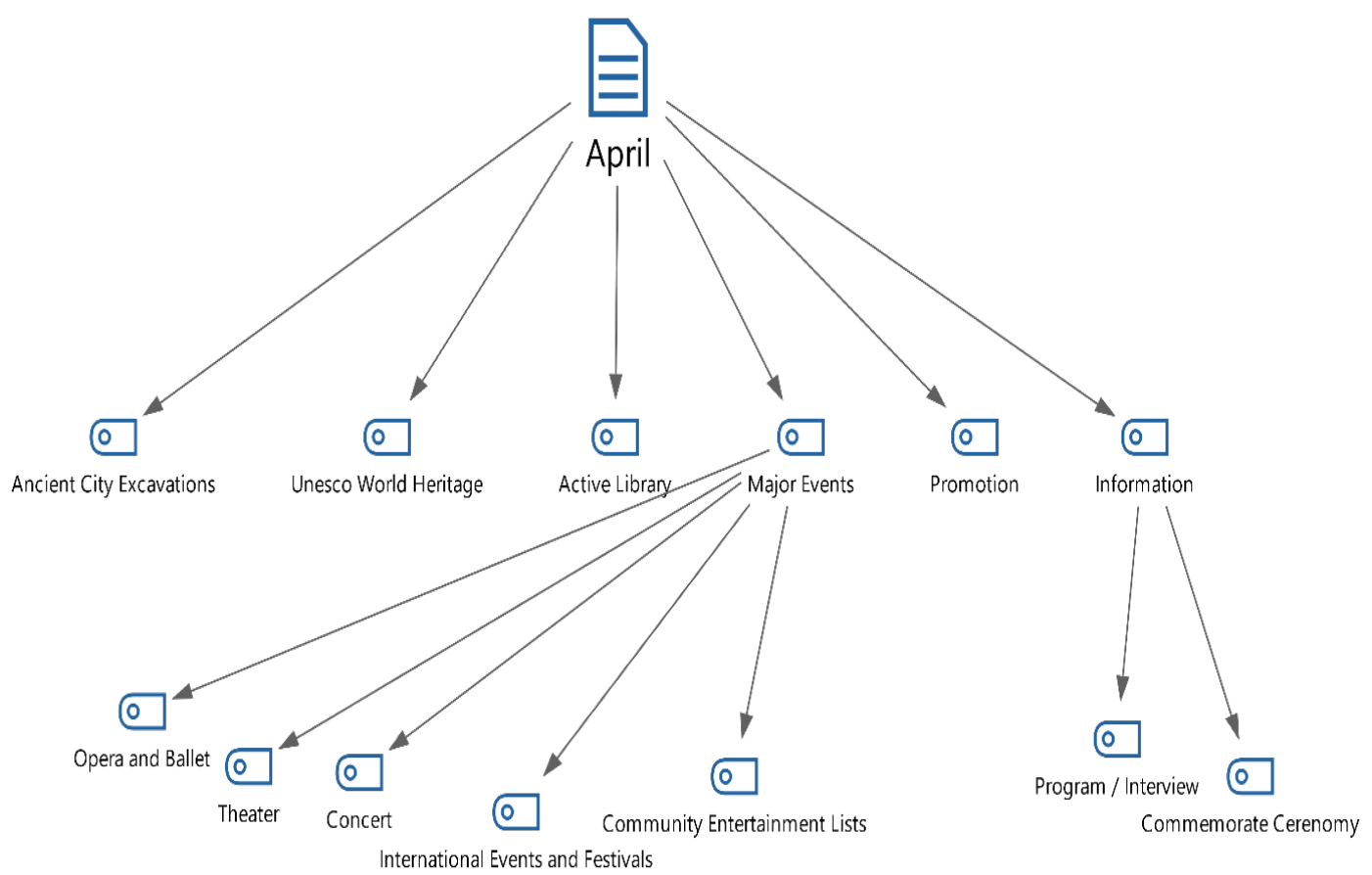

Figure 2. April tweet themes

The contents of the Ministry's Covid-19 pandemic's Twitter posts in April are as follows: The promotions of the ancient city excavation sites, the artifacts and places among the Unesco world heritage are promotional news and the practical library application. In the information category, in addition to the sharing of programs and interviews, messages to commemorate the artists who lost their lives were posted. There are opera and ballet performances, theater, concert sharing, international events, and festivals related to major online events. Finally, lists of online events aimed at entertaining the community are also available.

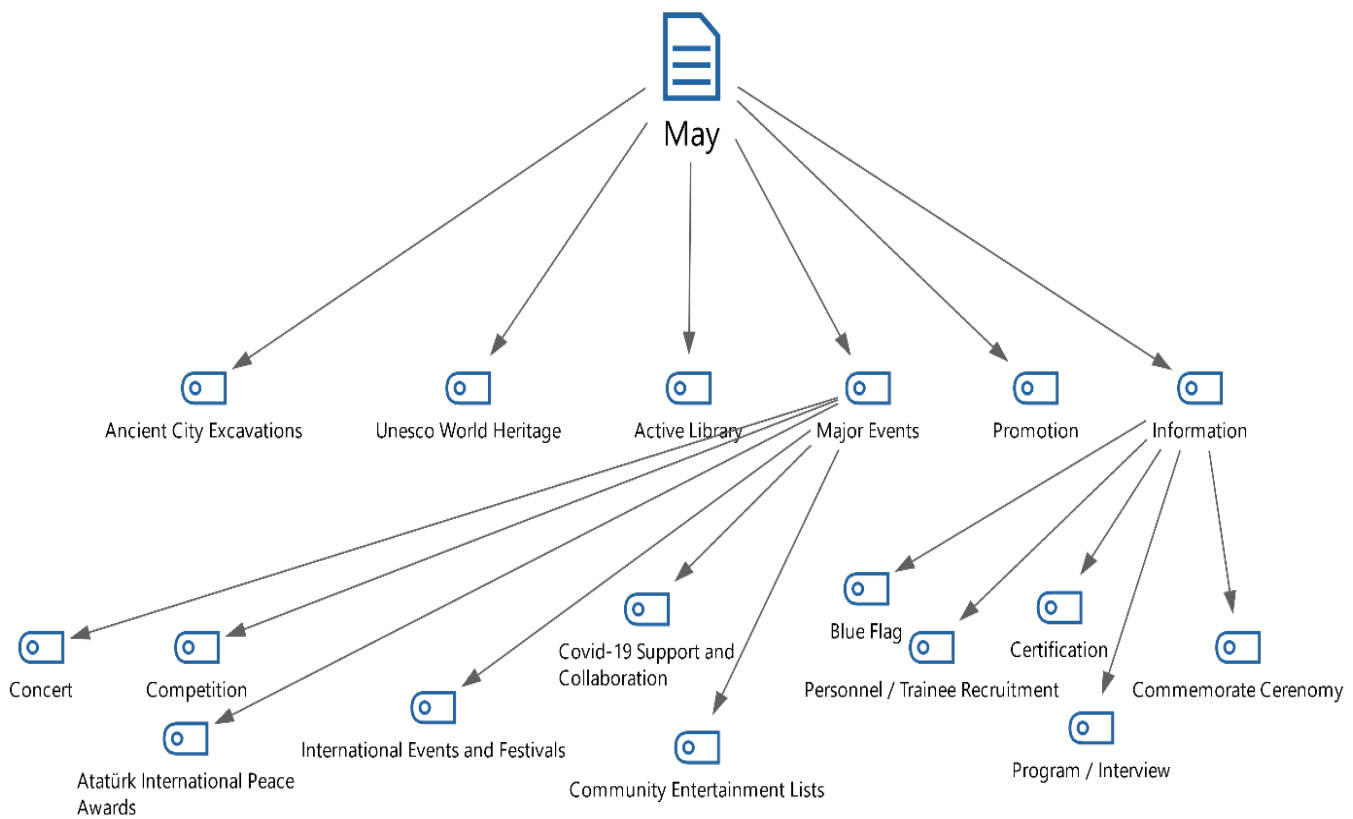

Figure 3. May tweet themes

With the announcement of the new normalization process in the Covid-19 pandemic, the contents of the Ministry's Twitter posts in May are as follows: The promotions of ancient 
city excavation sites, artifacts, and places among the Unesco world heritage continued to share promotional news as well as effective library practice. In the information category, in addition to the Blue Flag application, certification news, personnel/internship recruitment announcements, program and interview posts, messages to commemorate the artists who lost their lives were posted. Furthermore, all the sharing of competitions, concerts, Atatürk International Peace Awards, Covid-19 Support, and Cooperation activities related to major online events, there are lists of online activities aimed at entertaining the community.

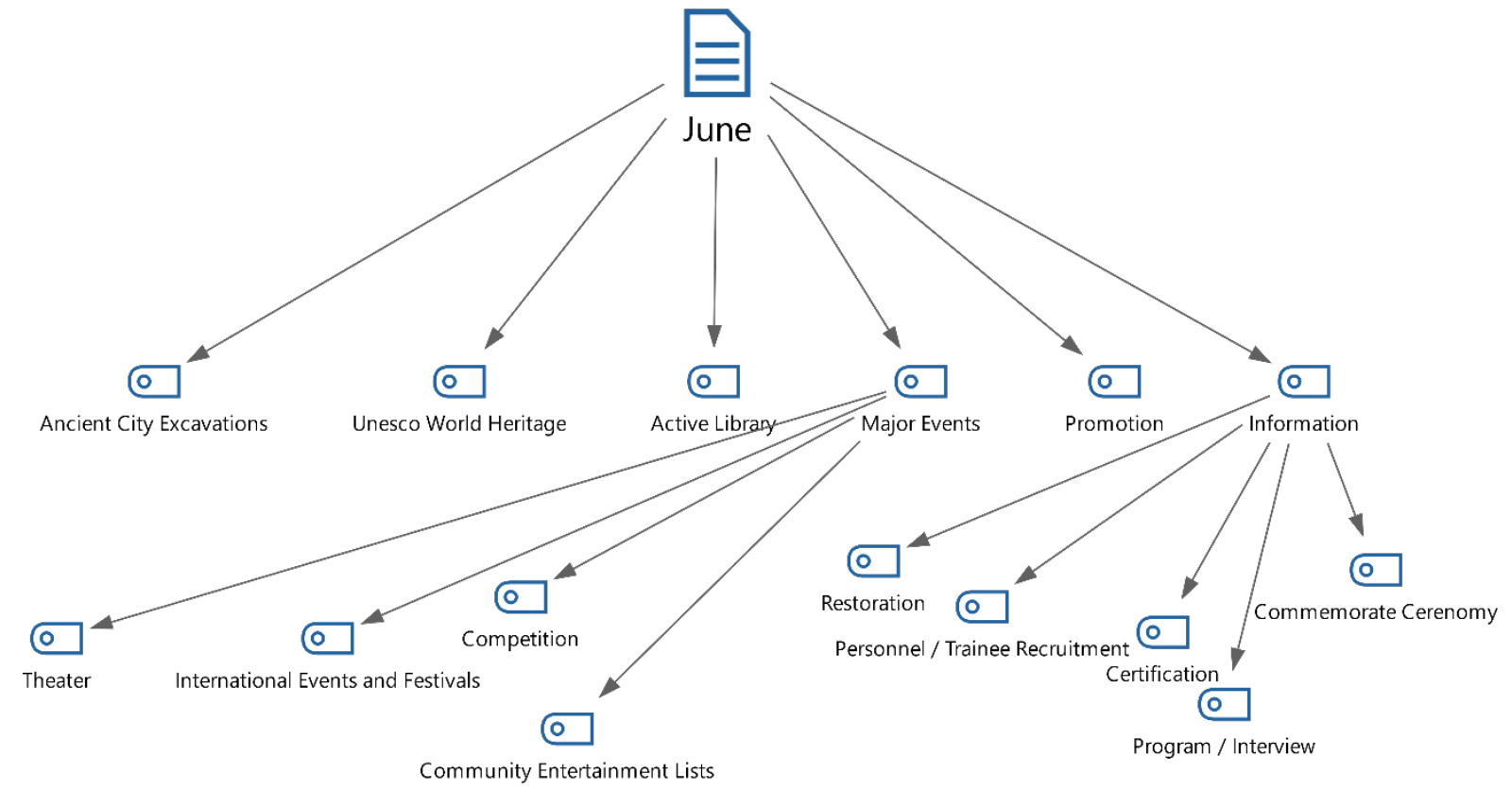

Figure 4. June tweets themes

With the application of the new normalization process in the Covid-19 pandemic, the contents of the Ministry's Twitter posts in June are as follows: The promotions of ancient city excavation sites, artifacts, and places among the Unesco world heritage continued to share promotional news as well as effective library practice. In the information category, restoration and certification news, staff/trainee recruitment announcements, programs and interviews, and commemorative messages for artists who lost their lives were posted. In addition to major online events, competitions, theater, international events, and festivals, there are lists of online events to entertain the community. 


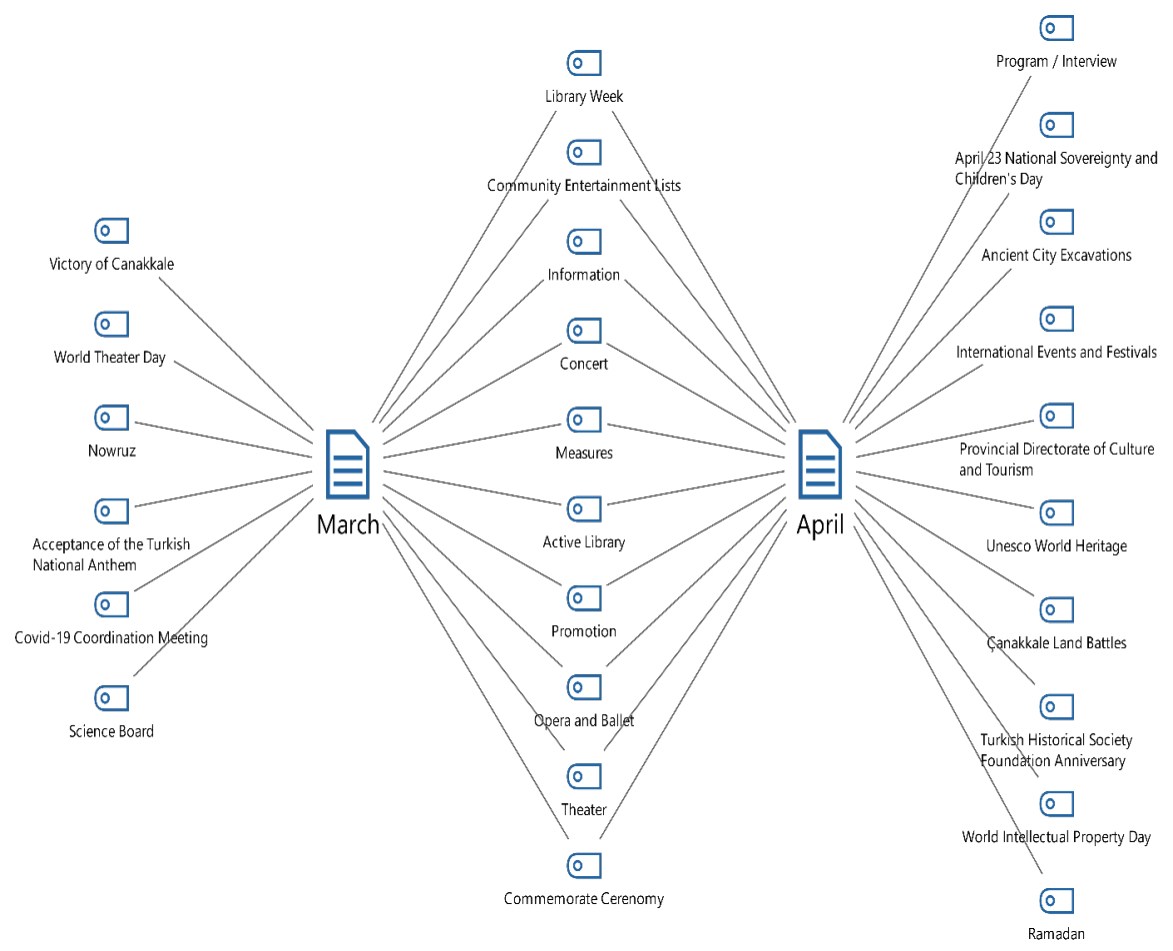

Figure 5. Comparison of march and April content

When the contents of March and April are compared, the typical subject contents are as follows: It contains the library week, lists of online activities aimed at entertaining the community, information, online concert, and measures. In addition to these sharing categories, a practical library application, promotional news, online opera, and ballet shows, theater news, and memorial messages for the artists who lost their lives were published. The differences in the content shared are particular day sharing, meetings, program/interviews, ancient city excavations, and organized activities.
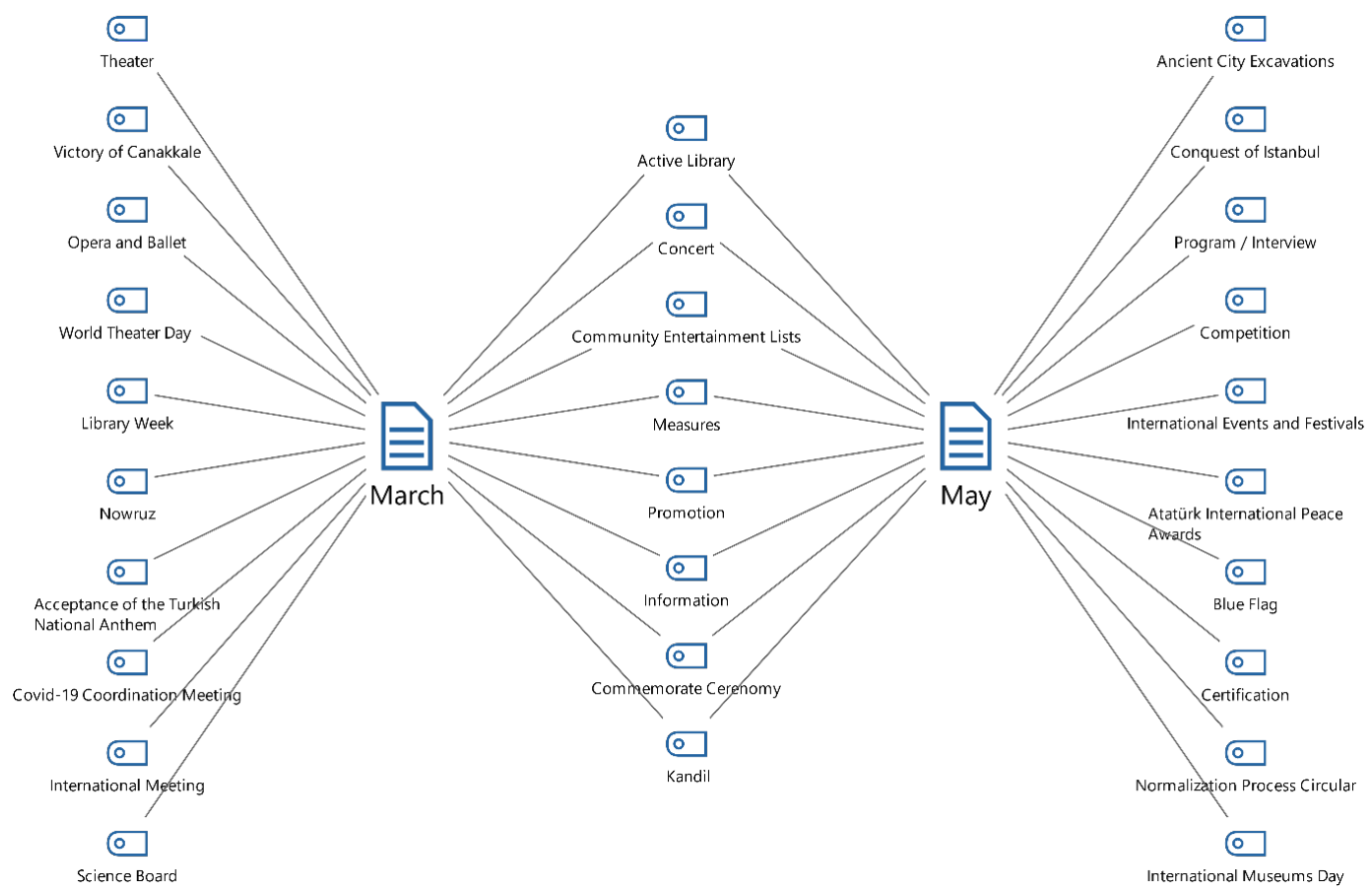

Figure 6. Comparison of March and may content 
When the contents of March, when the pandemic emerged, and May, when the new normalization process started, are compared, the standard subject contents are as follows: There are active library applications, online concerts, lists of online events for entertaining the community, Covid-19 measures, promotional announcements, information and finally commemorative messages for the artists who lost their lives. The content difference factors are special day shares, meeting contents, and organized events.

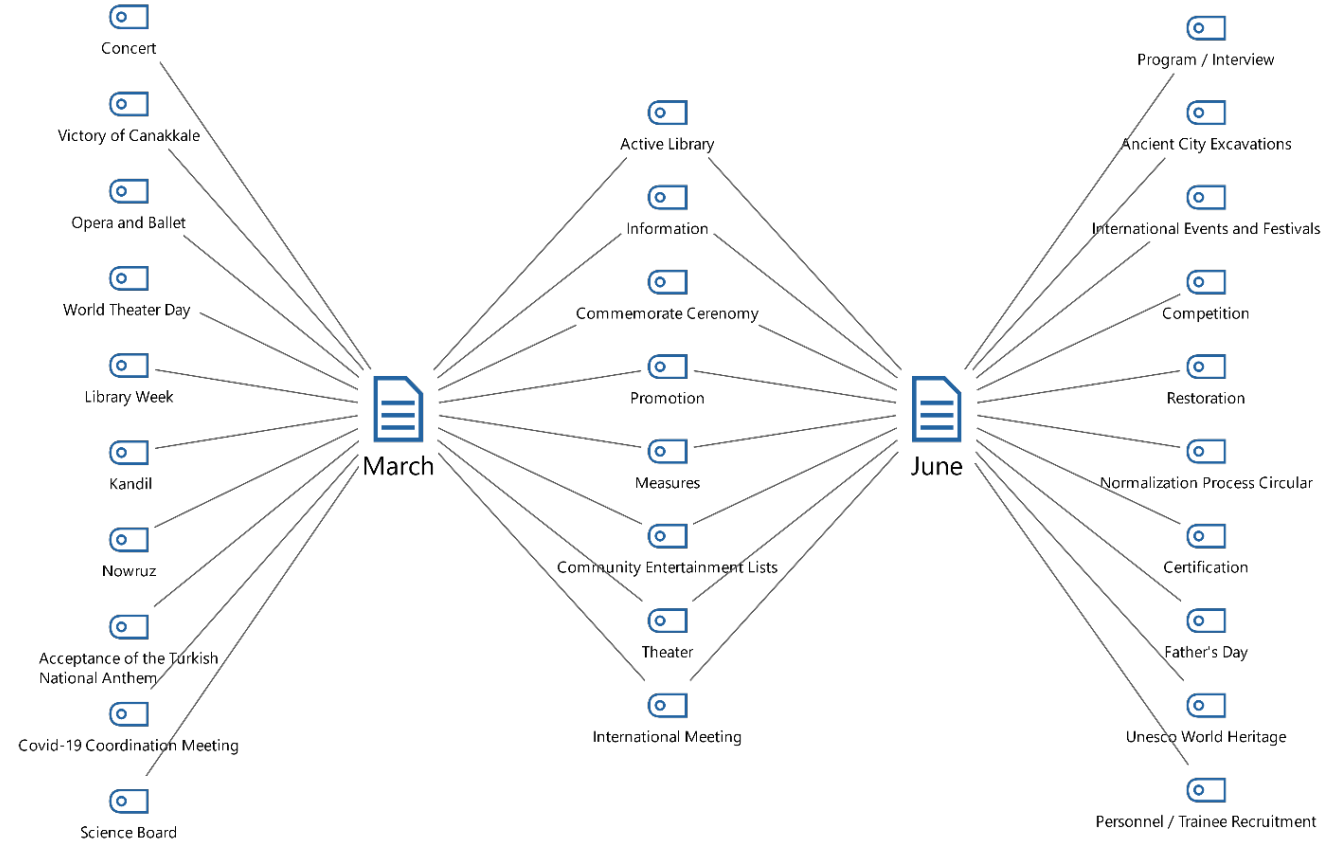

Figure 7. Comparison of march and June content

When the contents of March, when the pandemic emerged, and June, when the new normalization process continues, are compared, the standard subject contents are as follows: There are active library applications, theater, lists of online activities for the entertainment of the community, Covid-19 measures, promotional announcements, information, international meeting, and finally commemorative messages for the artists who lost their lives. The content difference factors are the special day shares, the contents related to the Unesco world heritage works and places, personnel/trainee recruitment announcements, meeting contents, and events.

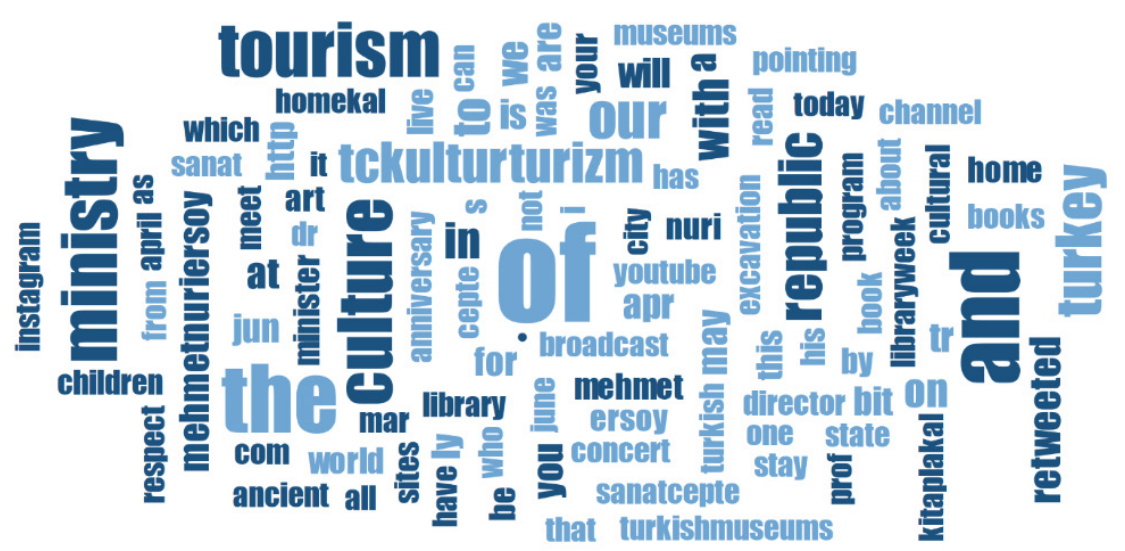

Figure 8. Ministry of culture and tourism twitter posts word cloud 
The famous words in the word cloud table attained as a consequence of the analysis of the official Twitter account of the Ministry are as follows: Turkey, culture, tourism, Ministry, republic, Turkish museums, channel, YouTube, Instagram, stay home, library week, books, antiques, art, anniversary, broadcast words are to the fore. It can be said that from March, when the Covid-19 pandemic was observed, until the end of June, when the new normalization process continued, the Ministry shared content in line with the area of interest, did not reflect the negative and pessimistic atmosphere created by the virus on Twitter posts, and shared content that would create positive connotations.

\section{Evaluation and Conclusion}

The Covid-19 pandemic, which started as a health crisis and later affected all areas of social life, appeared in Wuhan in December 2019. The coronavirus epidemic, which turned into a global crisis at the end of 2 months, affected the whole world. During this time, both individuals and governments began to use social media more actively, and therefore, with the effect of the epidemic, the volume of social media usage increased directly. Individuals from all segments of society had to turn to these virtual environments for many reasons, such as instant communication, faster transmission of information, and public security. In this process, the Ministry of Culture and Tourism actively had used its Twitter account to share informative content and online activities.

As one of the social media networks used by public institutions to communicate, collaborate and interact with citizens, Twitter is a platform that every segment of society can easily access. Institutions on this platform have the opportunity to improve and revise their communication with their target audiences. Public institutions try to strengthen their existing relations with citizens and organizations by keeping these social network platforms always up-to-date and interacting, and they can also announce events. When evaluated from this perspective, Twitter is an important communication channel that changes people's lives and behavior patterns with its economic and social life effects.

In the research, it is seen that the Twitter content of the Ministry showed a trend towards online activities with the beginning of the Covid-19 pandemic process. When the fourmonth sharing is analyzed, common sharing topics are the library week, lists of online activities for entertaining the community, information, online concerts, Covid-19 measures, practical library application, promotional news, online opera and ballet shows, theater, and commemorative messages. Considering the content of the tweets, it is observed that the Ministry has implemented many online activities at local and national scales in the process. The Ministry's digitalization of events makes these events widespread, and the event is shared by making photos, videos, or live broadcasts. Thus, the Ministry takes on a task that makes informative shares for events that entertain the Public by using its official Twitter account. In addition, it enables citizens to move away from the spread of harmful information created by the epidemic environment and promotes activities that will increase the positive feelings and thoughts of the society in this process.

During the Covid-19 pandemic, the demand for online concerts and virtual museum applications has increased following social distance practice and hygiene rules. Ramadan Feast concerts, national concert series, and award ceremonies were broadcast live on Instagram and Youtube accounts in this process. As in the pandemic process, online activity organization activities continued with the start of the normalization process as of May. With the normalization circular published in June, with the announcement 
that some transactions will be carried out online within the framework of the epidemic measures action plan, the planning and management process of digital events were organized on Twitter.

As a result, online concerts held for moral purposes for healthcare professionals during the pandemic process were held in many different countries such as Spain, England, China, the USA, and Italy. In this respect in Turkey, supporting the health workers and improving people's mood was conducted online events. Activities carried out in line with these purposes were planned and put into practice within the corporate vision and mission framework. Accordingly, as these events aroused interest, the number of followers of the Ministry's Twitter account has increased.

\section{References}

Akay, R. A. (2014). Etkinlik Yönetimi Uygulamalarında Yaratıcı Rekabet ve Sosyal Medyanın Entegrasyonu. The Turkish Online Journal of Design, Art and Communication, 4(4), 55-70.

Alhojarlan, M. I. (2012). Thematic analysis: A critical review of its process and evaluation. West East Journal of Social Sciences, 1(1), 39-47.

Anadolu Ajansı. (2021, January 21). January 21, 2021 tarihinde Anadolu Ajansı: https:// www.aa.com.tr/tr/koronavirus/salgin-sureci-konserleri-online-ortamatasidi/2093352 adresinden alındı

Becker, H., Naaman, M., \& Gravano, L. (2009). Event Identification in Social Media. ACM SIGMOD workshop on the web and databases (WebDB). içinde RI: Providence.

Berg, B., \& Howard , L. (2019). Sosyal Bilimlerde Nitel Araştırma Yöntemleri. (A. Hasan , Dü.) Konya: Eğitim Yayınevi.

Bertot, J. C., Jaeger, P. T., \& Grimes, J. M. (2010). Using ICTs to create a culture of transparency: E-government and social media as openness and anti-corruption tools for societies. Government Information Quarterly, 27(3), 264-271.

Bukhari, I., Wojtalewicz, C., Vorvoreanu, M., \& Dietz, E. (2012). Social media use for extensive event management: The application of social media analytic tools for the Super Bowl XLVI. IEEE Conference on Technologies for Homeland Security (HST) (s. 24-29). IEEE.

Castleberry, A., \& Nolen, A. (2018). Thematic analysis of qualitative research data: Is it as easy as it sounds? Currents in Pharmacy Teaching and Learning, 10(6), 807-815.

Cottrill, C., Gault, P., Yeboah, G., Nelson, J., Anable, J., \& Budd, T. (2017). Tweeting Transit: An examination of social media strategies for transport information management during a significant event. Transportation Research Part C: Emerging Technologies, 77, 421-432.

Criado, J., Sandoval-Almazan, R., \& Gil-Garcia, R. (2013). Government innovation through social media. Government Information Quarterly, 30, 319-326.

Dadashzadeh, M. (2010). Social Media In Government: From eGovernment To eGovernance. Journal of Business \& Economics Research, 8(11), 81-86.

Duğan, Ö., \& Bayram , O. A. (2018). Sosyal Medyanın Turizmde Tanıtım Amaçlı Kullanımı: TC Kültür ve Turizm Bakanlığı Örneği. Uluslararası Türk Dünyası Turizm Araştırmaları Dergisi, 3(1), 1-13. 
Getz, D. (2000). Developing a research agenda for the event management field. Events beyond, 10-21.

Goldblatt, J. J. (1997). Special events: best practices in modern event management. Van Nostrand Reinhold.

Göçoğlu, V. (2019). Türkiye'de Merkezi Yönetimin Sosyal Medya Kullanımı: Bakanlıkların Twitter Hesapları Üzerine Bir Analiz. Uluslararası Yönetim Akademisi Dergisi, 2(2), 422-444.

Gu, H., Xie, X., Lv, Q., Ruan, Y., \& Shang, L. (2011). Etree: Effective and efficient event modeling for real-time online social media networks. IEEE/WIC/ACM International Conferences on Web Intelligence and Intelligent Agent Technology. 1, s. 300-307. IEEE.

Hürriyet. (2021, January 21). January 21, 2021 tarihinde Hürriyet: https://www. hurriyet.com.tr/yazarlar/sinem-vural/guney-koreden-turkiyeye-biletli-onlinekonser-41549493 adresinden alındı

Işık, M. (2013). Halkla İlişkilere Giriş. (M. Işık, Dü.) Konya: Eğitim Yayınevi.

Işık, M., \& Ayhan, E. (2007). Meşruiyet, demokrasi, sosyal sorumluluk ve halkla ilişkiler. M. Işılk, \& E. Ayhan içinde, Tüm yönleriyle halkla ilişsiler ve tanıtım. Konya: Eğitim Yayınevi.

Jago, L. K., \& Shaw, R. N. (2000). Consumer perceptions of special events: A multistimulus validation. Journal of Travel \& Tourism Marketing, 8(4), 1-24.

Khasawneh, R. T., \& Abu-Shanab, E. (2013). E-government and social media sites: the role and impact. World Journal of Computer Application and Technology, 1(1), 10-17.

Marine-Roig, E., Martin-Fuentes, E., \& Daries-Ramon, N. (2017). User-generated social media events in tourism. Sustainability, 9(12), 2250.

Paris, C., Lee, W., \& Seery, P. (2010). The role of social media in promoting special events: acceptance of Facebook events. Information and Communication Technologies in tourism, 14, 531-541.

Pasanen, K., \& Konu, H. (2016). Use of social media for new service development by Finnish event and festival organizers. Event Management, 20(3), 313-325.

Peltekoğlu, F. (2012). Halkla ilişkiler nedir? İstanbul: Beta Yayınları.

Pino, G., Peluso, A. M., Del Vecchio, P., Ndou, V., Passiante, G., \& Guido, G. (2019). A methodological framework to assess social media strategies of event and destination management organizations. Journal of Hospitality Marketing \& Management, 28(2), 189-216.

Sabah. (2021, January 21). January 21, 2021 tarihinde https://www.sabah.com.tr/ yazarlar/gunaydin/funda-karayel/2020/12/26/turkiyenin-ilk-online-canlistadyum-konserinin-tek-izleyicisi-bendim-57-milyon-seyirciden-edise-onlinealkis adresinden alındı

Sayımer, İ. (2008). Sanal ortamda halkla ilişkiler. İstanbul: Beta Yayınları.

Syme, G. (1989). The planning and evaluation of hallmark events. (G. Syme, Dü.) Gower Publishing Company. 
T.C. Kültür ve Turizm Bakanlığı. (2021, January 1). January 1, 2021 tarihinde https:// twitter.com/TCKulturTurizm adresinden alındı

Ünlü, S. (2018a). A Study On The Reputation Rules Of Corporate Reputation. Üçüncü Sektör Sosyal Ekonomi, 53(3), 889-905.

Ünlü, S. (2018b). Yeşil Etkinlik Yönetimi Planlama ve Yaklaşımlar. Konya: Eğitim Yayınevi.

Vaismoradi, M., Jones, J., Turunen, H., \& Snelgrove, S. (2016). Theme development in qualitative content analysis and thematic analysis. Journal of Nursing Education and Practice, 6(5), 100-110.

Yıldırım, A. (2014). Bir Halkla İlişkiler Aracı Olarak Twitter: TC Sağlık Bak. Gümüşhane Üniversitesi İletişim Fakültesi Elektronik Dergisi, 2(4), pp. 234-253.

Yi, M., Oh, S., \& Kim, S. (2013, July). Comparison of social media uses for the U.S. and the Korean governments. Government Information Quarterly, 30(3), pp. 310-317. 


\section{Covid-19 Pandemisi Sürecinde Twitterda Online Etkinlik Yönetimi: Kültür ve Turizm Bakanlığı Örneği}

Simge Ünlü (Assoc. Prof. Dr.)

Lütfiye Yaşar (MA Student)

\section{Genişletilmiş Özet}

Sosyal medyanın popüler olmasında teknolojik gelişmeler ve internetin yayın kullanımının etkisi büyüktür. Bu yayınlaşmada gerek özel gerekse kamu kurum ve kuruluşların bu mecralarda yer alması da etkili olmaktadır. Kamu kurumları da hedef kitleleriyle ilișkilerini geliștirmek maksadıyla bu mecralara yönelmektedir. Kültür ve Turizm Bakanlığı da sosyal medya ortamlarında yer alarak kamu ve kamuoyuyla var olan iletişimini sürdürmektedir.

Geçmișten miras kalan eserlerin tanıtımında önemli bir role sahip olan Kültür ve Turizm Bakanlığı, bu mirasın özündeki değerleri tanımayı ve farkındalığı artırmayı hedeflemektedir. Bu nedenle iletişim kurduğu kurum ve kuruluşlarla birlikte etkili bir sosyal medya aracı olan Twitter'da faaliyet göstermektedir. 2019 yılında küresel bir salgına dönüşen Covid-19 pandemisi etkisiyle sokağa çıkma yasağı ilan edildi ve bu süreçten en çok etkilenen sektörlerden biri de turizm oldu. Yaşanan bu süreçte halk evlerine kapanarak sosyal medya üzerinden organize edilen etkinliklere katıldılar. Bu online etkinliklerin düzenleyicileri bazen bireyler bazen de kurumlar oldu. Cem Adrian youtube'da ücretsiz konser verirken, Şarkıcı Yalın da Instagram'da ilk canlı konserini verdi. Sedat Anar, Üsküdar Belediyesi'nin Instagram ve Youtube kanalındaki etkinliklerde konser verdi. Tüm bu etkinliklerin yanı sıra 23 Nisan Ulusal Egemenlik ve Çocuk Bayramı için düzenlenen online konser İletişim Başkanlığı YouTube kanalında yayınlandı (Anadolu Ajansı, 2021). İnternet üzerinden biletli konser düzenleyen BTS, satılan 756 bin 600 bilet ve 107 ülkeden katılımcıyla en çok izlenen konser oldu. Türkiye'de ilk biletli online konser deneyi Mor ve Ötesi tarafından gerçekleştirildi (Hürriyet, 2021). Türkiye'de düzenlenen ilk çevrimiçi canlı stadyum konseri YouTube'da 5,7 milyon kişi tarafından izlendi (Sabah, 2021).

Pandemiyle birlikte gelişen etkinlik endüstrisi ve düzenlenen aktiviteler medya araçlarının temel bir unsuru olduğu görülmektedir. Etkinliklerin ekonomik, kültürel, toplumsal yararlarına ek olarak eğitsel faydaları da bulunmaktadır. Toplumsal bir rol üstlenen etkinlikler, kurumsal temelli halkla ilişkilerin bir aracıdır (Ünlü, 2018b). Böylece kurumsal perspektifin yansıtılması, mesaj iletimi, ürün/hizmet tanıtımı, sorumlulukların dile getirilmesi ve son olarak pozitif bir imaj yaratmak için etkinlikler etkili bir yöntemdir.

Pandemiyle birlikte artan online etkinlik yönetimi toplumsal entegrasyon yahut kurumun benimsediği sosyal sorumluluk algısına ek olarak imaj ve itibar gibi kurumsal amaçları güçlendirmek için yapılacak kutlama, toplantı veya tanıtımlar gibi aktiviteleri tüm yönleriyle planlamak, süreci yönetmek ve devamında değerlendirmeleri içeren sürecin tamamını kapsamaktadır (Peltekoğlu, 2012; Işık \& Ayhan, 2007; Işık, 2013). Bundan dolayı online etkinlik yönetimi reklam ve tanıtıma ek olarak lobicilik gibi spesifik yöntem ve aşamaları olan planlı ve özverili çalışmayla birlikte bir emeği anlatmaktadır.

Araştırmanın amacl, Covid-19 pandemisinin ülkemizi yoğun bir şekilde etkilemeye başladığı dönemde Kültür ve Turizm Bakanlı̆̆ı'nın mikroblog sitesi olarak tanımlanan 
sosyal medya uygulamalarından Twitter'ın kullanımını online etkinlik yönetimi bakımından analiz etmektir. Bu çalışma etik kurul onayına tabi olmayan araștırma grubuna dahildir Literatürde kamu kurumlarının sosyal medya etkinlik yönetimi ile ilgili yeterli çalışma bulunmadığından pandemi sürecinde online etkinlikler düzenleyen Kültür ve Turizm Bakanlığg'nın Twitter kullanımının incelenmesi ve sonuçların değerlendirilmesi oldukça önemlidir. Ek olarak, bu araştırma gelecekteki çalışmalara referans sağlaması açısından önemlidir. Bakanlığın 11 Mart - 30 Haziran 2020 tarihleri arasında resmi sosyal medya hesabı Twitter'da paylaştığı Tweetleri tematik analiz yöntemi ile incelemiştir. Araştırma, Maxqda 2020.03 sürümü ile analiz edilmiştir. Araştırmanın soruları şu şekilde sıralanmıştır:

Covid-19 salgını sırasında bakanlığın Twitter'daki çevrimiçi etkinlik paylaşımlarının içerikleri neler?

Covid-19 salgını sırasında Kültür ve Turizm Bakanlığı, çevrimiçi bir etkinlik düzenlediği için Twitter'da takipçi sayısını artırdı mı?

Bakanlık, Covid-19 salgını sırasında halkı eğlendirmek için Twitter'ı kullandı mı?

Araştırma sonucunda bakanlığın Twitter içerikleri, Covid-19 pandemisi sürecinin başlangıcıyla online etkinliklere yönelik bir eğilim gösterdiği görülmektedir. Dört aylık paylaşım analiz edildiğinde ortak paylașım konuları kütüphane haftası, topluluğun eğlendirilmesine yönelik online etkinliklerin listeleri, bilgilendirme, online konser, Covid-19 tedbirleri, etkin kütüphane uygulaması, promosyon haberleri, online opera ve bale gösterileri, tiyatro ve anma mesajlarıdır. Tweet içerikleri göz önüne alındığında ise bakanlığın süreç içerisinde yerel ve ulusal ölçekte birçok online etkinlik planlanmasını hayata geçirdiği gözlenmektedir. Bakanlığın etkinlikleri dijital ortama taşıması bu etkinleri yaygın hala getirmekte ve etkinlik anına dair fotoğraf, video ya da canlı yayınlar yaparak paylaşım yapılmaktadır. Böylece bakanlık resmi Twitter hesabından yararlanarak kamuoyunu eğlendiren etkinlikler için bilgilendirici paylaşımlar yapan bir görev üstlenmekte ve vatandaşların salgın ortamının yarattığı negatif enformasyonun yayılımından uzaklaşmasını sağlayarak toplumun bu süreçte pozitif duygu ve düşüncelerini artıracak etkinliklerin tanıtımını yapmaktadır.

Covid-19 pandemisi kapsamında sosyal mesafe uygulaması ve hijyen kuralları gereğince online konserlere ve sanal müze uygulamalarına talep artmıştır. Bu süreçte Ramazan Bayramı konserleri, 23 Nisan konser dizileri, ödül törenleri instagram ve youtube hesaplarından canlı yayınlanmıştır. Pandemi sürecinde olduğu gibi mayıs ayı itibariyle normalleşme sürecinin başlamasıyla online etkinlik düzenleme faaliyetlerine devam edilmiştir. Haziran ayında yayınlanan normalleşme genelgesiyle salgın önlemleri eylem planı çerçevesinde bazı işlemlerin çevrimiçi gerçekleşeceğinin duyurulmasıyla birlikte dijital etkinliklerin planlanması ve yönetimi süreci Twitter üzerinden organize edildiği görülmektedir.

Sonuç olarak, pandemi sürecinde online etkinliklerin kurumsal vizyon ve misyon çerçevesinde doğru planlanıp uygulamaya konulması sonucunda hedef kitlede ilgi uyandırarak bakanlığın Twitter hesabının takipçi sayısında artış sağlamıştır.

Anahtar Kelimeler: Halkla İlişkiler, Online Etkinlik Yönetimi, Sosyal Medya, Kültür ve Turizm Bakanlığı, Covid-19 Pandemi. 
Bu makale intihal tespit yazııımlarıyla taranmıştır. Intihal tespit edilmemiştir.

This article has been scanned by plagiarism detection softwares. No plagiarism detected.

Bu çalışmada "Yükseköğretim Kurumları Bilimsel Araştırma ve Yayın Etiği Yönergesi” kapsamında uyulması belirtilen kurallara uyulmuştur.

In this study, the rules stated in the "Higher Education Institutions Scientific Research and Publication Ethics Directive" were followed.

Yazarların çalışmadaki katkı oranları; birinci yazar $\% 55$, ikinci yazar $\% 45$.

Contribution rates of the authors in the study; first author $55 \%$, second author $45 \%$.

Çalışma kapsamında herhangi bir kurum veya kişi ile çıkar çatışması bulunmamaktadır.

There is no conflict of interest with any institution or person within the scope of the study. 